\title{
DETEKSI SENYAWA METABOLIT SEKUNDER JAMUR ENDOFIT DARI AKAR TANAMAN KARET (Hevea brasiliensis)
}

\author{
Widya Lestari dan Aini Qomariah Manurung \\ Program Studi Agroteknologi Sekolah Tinggi Ilmu Pertanian Labuhanbatu \\ Jln. SM. Raja No 126 A Aek Tapa Labuhanbatu Sumatera Utara \\ e-mail : widya.chubby@yahoo.co.id
}

\begin{abstract}
Endophytic fungi are a group of fungi whose part or whole life is in living plant tissue and usually does not harm the host. Endophytic fungi generally produce secondary metabolites that have beneficial biological activities such as anti-cancer compounds, antifungi or antibacterials. Control of plant diseases caused by Rigidoporus microporus and Ganoderma boninense can be done by using biological agents, namely by using endophytic fungi. This fungus has metabolite compounds that can inhibit the growth of Rigidoporus microporus and Ganoderma boninense. This study aims to determine what content is found in endophytic mushroom extracts isolated from rubber plants (Hevea brasiliensis). Endophytic fungi are extracted by maceration using methanol and ethyl acetate solvents. The extract was tested for antifungal activity using diffusion method. The content of secondary metabolites was tested by phytochemical test. The results of endophytic fungal extraction with methanol and ethyl acetate solvents resulted in antifungal activity with inhibitory zones in a row namely WLO1: 2.19 and $2.15 \mathrm{~mm}$ Fungi Isolates on Ganoderma boninense while $3.09 \mathrm{~mm}$ WLO2 against Rigidoporus microporus Based on the phytochemical test results, endophytic fungal extract with methanol and ethyl acetate solvents showed the presence of alkaloid, flavonoid, phenol and saponin.
\end{abstract}

Keywords: endofit, fungi, hevea, secondary metabolites

\section{PENDAHULUAN}

\subsection{Latar Belakang}

Pencarian sumber senyawa bioaktif terus menerus dilakukan seiring dengan semakin banyaknya penyakit pada tanaman. Senyawa bioaktif dapat diperoleh dari beberapa sumber, diantaranya dari tumbuhan, hewan, mikroba dan organisme laut (Prihatiningtias, 2005).

Salah satu sumber senyawa bioaktif yang dewasa ini menjadi populer adalah yang berasal dari mikroba. Salah satu mikroba penghasil senyawa bioaktif adalah jamur endofit yang merupakan jamur yang tumbuh dan mengkolonisasi di jaringan tumbuhan (inang) terutama di bagian akar, batang dan daun. Jamur endofit dapat menghasilkan senyawasenyawa bioaktif dan metabolit sekunder yang sama dengan inangnya. Hal ini diduga karena jamur endofit mengalami koevolusi transfer genetik dari inangnya. Kemampuan mikroba endofit dalam menghasilkan senyawa bioaktif merupakan hal yang sangat potensial untuk dikembangkan menjadi obat herbal. Hal ini karena mikroba endofit merupakan mikroorganisme yang mudah ditumbuhkan, memiliki siklus hidup yang pendek dan dapat menghasilkan jumlah senyawa bioaktif dalam jumlah besar dengan metode fermentasi.

Menurut Cook dan Baker (1983), usaha penanggulangan penyakit tanaman secara biologis mempunyai peluang yang cukup besar karena organismenya telah tersedia di alam dan aktivitasnya dapat 
distimulasi dengan memodifikasi lingkungan maupun tanaman inang. Keuntungan dalam menggunakan mikroorganisme antagonis sebagai pengendalian biologis antara lain: aman terhadap lingkungan, tidak ada efek residu, aplikasinya bersifat berkelanjutan karena yang digunakan organisme hidup yang dapat memperbanyak diri sehingga dapat mengurangi aplikasi yang berulangulang. Penelitian jamur endofit telah dilakukan lebih dari 20 tahun yang lalu. Hampir setiap bagian tanaman ditemukan adanya jamur endofit, baik pada daun, akar maupun batang. Dalam beberapa tahun terakhir, pengaplikasian mikroba endofit sebagai pengendali biologis telah menjadi alternatif untuk menggantikan peran pengendali kimia seperti pestisida. Penggunaan agen biologis ini secara alami mampu mengendalikan populasi hama, meningkatkan produksi tanaman dan merupakan pilihan yang baik bagi resistensi penyakit dan juga ramah lingkungan (Procopio et al., 2009).

\subsection{Tujuan Penelitian}

Untuk mencari sumber penghasil senyawa bioaktif tanpa mengekstrasi tanaman yaitu dengan cara mengisolasi dan mengidentifikasi jamur endofit dari akar tanaman karet serta mengkaji kandungan metabolit sekunder yang diperoleh jamur endofit tersebut.

\section{METODOLOGI PENELITIAN}

\subsection{Bahan dan Alat}

Bahan yang digunakan dalam penelitian ini antara lain akar tanaman karet, medium PDA, kloramfenikol, metanol, etl asetat, aquades, etanol $70 \%$, $\mathrm{NaOCl}$, kertas saring, kloroform, pereaksi semprot DPPH, $\mathrm{H} 2 \mathrm{O} 2$ 3\%, Lieberman, dragendrof.

Alat yang digunakan dalam penelitian ini antara lain: oven, autoklaf, laminar air flow, rotary shaker, refrigerator, inkubator, mikroskop, sentrifus, lemari asam, tabung sentrifuse, timbangan digital, kompor listrik, corong, labu Erlenmeyer, gelas kimia, cawan Petri, pembakar Bunsen, gelas ukur, plastik pembungkus, aluminium foil, swab, pipet volumetrik, pinset, mikropipet, spatula, gunting, pisau steril, koran, plastik, vortex mixer, chamber,kapas, kertas label, ose, da $n$ penggaris.

\subsection{Prosedur Penelitian}

\section{Pemurnian Jamur Endofit}

Jamur endofit yang telah tumbuh pada media isolasi PDA, kemudian secara bertahap dimurnikan satu persatu. Masingmasing isolat murni jamur endofit yang diperoleh, kemudian dipindahkan ke dalam media dalam PDA di cawan Petri. Pemurnian ini bertujuan untuk memisahkan koloni endofit dengan morfologi berbeda untuk dijadikan isolat tersendiri. Pengamatan morfologi dilakukan kembali setelah inkubasi selama 5-7 hari, dan apabila masih ditemukan pertumbuhan koloni yang berbeda secara makroskopik maka harus dipisahkan kembali sampai diperoleh isolat murni. Jamur endofit diinkubasi pada suhu kamar selama 3-5 hari sesuai dengan pertumbuhannya. Setiap isolat murni dibuat duplo. Masing-masing sebagai kultur stok dan kultur untuk penelitian.

\section{Pembuatan Ekstrak Jamur Endofit Ekstraksi Bahan Antifungal dari Isolat Jamur Endofit}

Ekstraksi metabolit sekunder jamur endofit akar tanaman karet (Hevea brasiliensis) yang memiliki aktivitas antifungal dilakukan berdasarkan metode yang pernah dilakukan oleh Nofiani et al. (2009) dan Suryanto et al. (2012) yang dimodifikasi. Isolat jamur endofit yang paling potensial diperbanyak di media PDA dan diinkubasi selama 5 hari. Media PDA selanjutnya dipotong kecil-kecil dan direndam dengan metanol dan etil asetat dalam erlenmeyer selama 72 jam dan dibungkus dengan kertas aluminium untuk mengindari kerusakan karena cahaya. 
Maserat diambil dengan cara disaring. Perendaman dilakukan sebanyak 3 kali. Semua maserat yang terkumpul disentrifugasi dengan kecepatan 3000 rpm selama 15 menit. Supernatan dipekatkan dengan menggunakan rotariepavorator dengan suhu tidak lebih dari $50^{\circ} \mathrm{C}$ untuk memperoleh ekstrak yang siap untuk digunakan. Metode yang sama dilakukan terhadap pelarut $n$-heksana dan etil asetat.

\section{Deteksi Kandungan Ekstrak Metanol dan Etil Asetat Isolat Jamur Endofit}

Untuk mendeteksi kandungan senyawa dari ekstrak methanol dan etil asetat isolat jamur endofit dari akar tanaman karet, maka dilakukan analisis skrining fitokimia meliputi pemeriksaan kandungan senyawa alkaloida, flavanoida, terpenoid/steroida, tanin dan saponin menurut prosedur yang telah dilaporkan Harbone (1996) (Tabel 1). Ekstrak metanol dan etil asetat yang telah diperoleh dari prosedur sebelumnya dideteksi dengan menggunakan metode fitokimia untuk uji pendahuluan agar diketahui kandungan senyawa pada ekstrak bakteri endofit yang dibuat yaitu alkaloid, terpenoid, fenolik, flavonoid dan saponin.

Tabel 1. Metode Skrining Fitokimia menurut Harbone 1996

\begin{tabular}{|c|c|c|c|c|}
\hline No & Uji & Pereaksi & Hasil & Perubahan warna \\
\hline 1. & Fenolik & $\mathrm{FeCl} 31 \%$ & Positif & $\begin{array}{l}\text { Terbentuk larutan warna hijau, } \\
\text { biru, hitam }\end{array}$ \\
\hline 2. & Flavanoid & $\mathrm{Mg}-\mathrm{HCl}$ & Positif & Merah jambu \\
\hline 3. & Alkaloid & $\begin{array}{l}\text { Wagner, Mayer dan } \\
\text { Dragendroff. }\end{array}$ & Positif & Terbentuk endapan \\
\hline 4. & Steroid & $\begin{array}{l}\mathrm{H} 2 \mathrm{SO} 4(\mathrm{p}) \text { dan pereaksi LB } \\
\text { (Lieberman_Burchad). }\end{array}$ & Positif & Terbentuk warna hijau kebiruan \\
\hline 5. & Saponin & Akuades & Positif & Terbentuk busa \\
\hline 6. & Tanin & $\mathrm{FeCl} 3$ & Positif & Terbentuk warna hijau kebiruan, \\
\hline
\end{tabular}

\section{HASIL DAN PEMBAHASAN}

Dari hasil isolasi jamur endofit sampel akar tanaman karet diperoleh 5 isolat bakteri: WL01, WL02, WL03, WL04 dan WL05 yang memiliki potensi menghambat pertumbuhan jamur patogen. Kemampuan menghambat isolat bakteri ditunjukkan dengan terhambatnya pertumbuhan jamur Rigidoporus microporus dan Ganoderma boninense. Isolat jamur endofit WL01 dan WL02 merupakan isolat jamur yang paling potensial. Dari hasil uji daya hambat Ekstrak Metanol jamur endofit terhadap Jamur Rigidoporus microporus dan Ganoderma bininense diperoleh hasil sebagai berikut: Pada konsentrasi $80 \%$ ekstrak methanol isolat jamur WL01 memiliki zona hambat sebesar 2,19 mm terhadap jamur Ganoderma boninense dan sebesar 3,03 $\mathrm{mm}$ terhadap Rigidoporus microporus. Sedangkan Pada konsentrasi
$60 \%$ ekstrak metanol isolat jamur WL02 memiliki zona hambat sebesar $13,89 \mathrm{~mm}$ terhadap jamur Ganoderma boninense.

Ekstrak metanol dari kedua isolat jamur endofit WL01 dan WL02 dideteksi kelompok metabolit sekundernya secara umum berdasarakan uji skrining fitokimia sederhana (Tabel 2).

Tabel 2. Hasil Skrining Fitokimia Ekstrak Metanol Jamur Endofit WL01 dan WL02

\begin{tabular}{cccc}
\hline No & Uji & \multicolumn{2}{c}{ Hasil Kualitatif } \\
& & Ekstrak & Ekstrak \\
& & WL01 & WL02 \\
\hline 1 & Fenol & ++ & +++ \\
2 & Flavanoid & +++ & +++ \\
3 & Alkaloid & +++ & + \\
4 & Steroid & - & - \\
5 & Saponin & + & ++ \\
6 & Tanin & - & - \\
\hline
\end{tabular}

Dari Tabel 2 dapat dilihat bahwa isolat jamur endofit terpilih (WL01 dan 
WL02) mengandung kelompok senyawa metabolit sekunder alkaloid yang ditandai dengan timbulnya noda berwarna coklat pada saat sebelum maupun sesudah disemprot dengan pereaksi kimia dragendorff. Uji metabolit sekunder uji alkaloid ini bertujuan untuk mengetahui adanya senyawa golongan alkaloid dengan menggunakanpereaksi warna Dragendorff. Hasil uji alkaloid yang telah dilakukan menghasilkan larutan dengan warna oranye yang apabila dibiarkan beberapa saat akan menghasilkan endapan berwarna oranye kecoklatan pada dasar tabung. Hal ini menunjukkan hasil positif untuk golongan alkaloid. Adanya senyawa golongan alkaloid ditunjukkan dengan adanya endapan berwarna oranye dengan pereaksi Dragendorff. Mekanisme kerja alkaloid sebagai antibakteri yaitu dengan cara mengganggu komponen penyusun peptidoglikan pada sel bakteri sehingga lapisan dinding sel tidak terbentuk secara utuh dan menyebabkan kematian sel tersebut. Mekanisme lain antibakteri alkaloid yaitu komponen alkaloid diketahui sebagai interkelator DNA dan menghambat enzim topoisomerase sel bakteri (Karou et al., 2005).

Isolat jamur endofit terpilih (WL01) juga mengandung kelompok senyawa metabolit sekunder flavonoid yang ditandai dengan timbulnya noda berwarna kuning coklat pada saat sebelum maupun sesudah disemprot dengan pereaksi kimia uap amoniak. Isolat jamur endofit terpilih (WL01 dan WL02) tidak mengandung kelompok senyawa metabolit sekunder tanin dan steroid dikarenakan noda yang dihasilkan berwarna kuning sebelum disemprot dengan pereaksi kimia $\mathrm{FeCl} 310 \%$ dan setelah disemprot dengan pereaksi kimia $\mathrm{FeCl} 310 \%$ terlihat tidak adanya noda yang dihasilkan.

\section{KESIMPULAN}

Skrining fitokimia dengan menggunakan metode Harbone ekstrak methanol isolat jamur endofit WL01 dan
WL02 mengandung kelompok senyawa metabolit sekunder, yaitu Fenolik, Flavanoid, Alkaloid dan Saponin.

\section{UCAPAN TERIMAKASIH}

Penulis mengucapkan terima kasih yang sebesar besarnya kepada DPRM RISTEK DIKTI yang telah memberikan bantuan dana Hibah Penelitian Dosen Pemula Pendanaan Tahun 2018, sehingga penelitian dosen pemula ini bisa berjalan maksimal dan semoga bermanfaat bagi saya dan institusi STIPER LABUHAN BATU.

\section{DAFTAR PUSTAKA}

Cook RJ, Baker KF. 1983. The Nature of Practice of Biological Control of Plant Pathogens. The APS Press, St. Paul, Minnesota. 53 p.

Harborne J. 1996. Metode Fitokimia: Penuntun Cara Modern Menganalisis Tumbuhan. Cetakan kedua. Penerjemah: Padmawinata, K. dan Soediro, K. Bandung: Penerbit ITB.

Karou D, Savadogo A, Canini A, Yameogo S, Montesano C, Simpore J, Traore AS. 2005. Antibacterial Activity of Alkaloids From Sida acuta. African Journal of Biotechnology, 4(12), 195-200.

Nofiani R, Nurbetty S dan Sapar A. 2008. Aktifitas Antimikroba Ekstrak Metanol Bakteri Berasosiasi Spons dari Pulau Lemukutan, Kalimantan Barat. E-Journal dan Teknologi kelautan Tropis. 1: 33-41.

Prihatiningtias, Widyati. 2005. Prospek Mikroba Endofit Sebagai Sumber Senyawa Bioaktif. Yogyakarta : Fakultas Kedokteran Universitas Gadjah Mada

Procopio REL, Araujo W, Maccheroni Jr, Azevedo JL. 2009. Characterization of an Endophytic Bacterial Community Associated 
With Eucalyptus spp. Genet Mol Res 8 (4): 1408-1422.

Suryanto D, Siti KN, Erman M. 2012. Antimicrobial Activity of Some Bacterial Isolates natural
Recreational Park of North Sumatera, Indonesia. Bulletin of Environment, Pharmacology and Life Sciences. 1(11). 1-7. 